\title{
Self-Biting with Multiple Finger Amputations following Spinal Cord Injury
}

Patricia A. Dahlin, B.S.Pharm., Pharm.D., ${ }^{\star 1}$ Nancy E. Van Buskirk, M.A., ${ }^{2}$ Ronald W. Novotny, Ph.D., ${ }^{1}$ Isabelle R. Hollis, M.S.N., R.N. ${ }^{1}$ and John George, M.D., F.R.C.S. ${ }^{1}$

${ }^{1}$ Spinal Cord Injury Unit. ${ }^{2}$ Medical Library. Fames A. Haley Veterans Administration Hospital, Tampa, Florida, U.S.A.

\section{Summary}

We have observed mutilative self-biting leading to multiple finger amputations in two patients following $C_{4}$ complete spinal cord injury (SCI). Both men were of normal intelligence without psychosis and each had a neurotic personality and history of fingernail biting. They related the self-biting to anxiety and depression. We believe these to be the first English language reports of multiple finger amputations due to self-biting following SCI.

Key words: Spinal cord injuries; Tetraplegia; Self mutilation; Fingers.

\section{Introduction}

Within the general population, the most prevalent self-destructive oral habit is fingernail biting, a subject which has received a good deal of attention in the English language medical literature (Azrin, 1980; Ballinger, 1970; Barmann, 1979; Birch, 1955; Bornstein, 1980; Bucher, 1968; Clark, 1970; Davidson, 1980; Deardorff, 1974; Ellerbroek, 1978; Gruenewald, 1965; Hill, 1946; Horne, 1980; Klatte, 1981; Koupernik, 1964; Lowry, 1965; Malone, 1952; Massler, 1950; McKerracher, 1967; McNamara, 1972; Pennington, 1945; Wechsler, 1931). Such behaviour is usually subtle and often goes unnoticed. More vigorous self-biting resulting in trauma of the upper extremities has been seen with some regularity in psychiatric institutions (Ballinger, 1971). We have observed two unique cases of progressive self-biting of the fingers and hands, resulting in extensive mutilation including multiple finger amputations, in individuals of normal intelligence who displayed this behaviour following spinal cord injury (SCI). Both patients bit their fingernails prior to SCI.

^Address all correspondence to: Dr P. A. Dahlin, SCI Unit, 128, James A. Haley VA Hospital, 13000 N. 30th St., Tampa, FL U.S.A. 
In seeking background information on possible causes of the biting behaviour we observed, we performed a computerised search of the literature utilising both the PsychINFO data base and the National Library of Medicine's MEDLINE data base. We were unable to identify reports of cases similar to ours and we believe these to be the first English language reports of multiple finger amputations due to self-biting following SCI.

\section{Case reports}

Case 1

While away without leave from the Army during the Viet Nam Conflict, a 21-year-old man, under the influence of multiple centrally-acting drugs, dived into shallow water and sustained a $\mathrm{C}_{4}$ complete SCI with transitional levels at $\mathrm{C}_{5-6}$. He had a history of seizure disorder from childhood head trauma and history of heroin addiction. He underwent decompressive laminectomy in a non-government hospital and was placed in a nursing home with no rehabilitation training. He received an undesirable discharge from the Army. He continued to abuse ethanol and was discharged from numerous nursing homes over the next 8 years. A difficult relationship with his father precluded his living at home. After revised policy converted his military discharge status, he was admitted to our facility. On physical examination, the right index finger had been amputated to the middle of the proximal phalanx and the distal phalanx of the right ring finger had been partially amputated. Most of the nails of the left hand were gone. He explained that he had chewed the fingers and nails off. Serum chemistry and haematology, chest roentgenogram, and electrocardiogram were within normal limits. He was taking no prescription medication. Phenytoin had been discontinued years earlier. Psychological: Past history was significant for childhood hyperactivity and nailbiting. Nailbiting recurred after SCI, when he was drug-free. The patient admitted to anxiety and depression during the 8 post-SCI years, when he began nibbling his fingers. He viewed his self-biting as an extension of nailbiting and had not been inclined to stop. There were indications of restlessness, impulsivity, and low frustration tolerance. He was alert, cooperative, oriented in all spheres, and exhibited no bizarre symptomatology. He was of average intelligence with good abstract reasoning ability and adequate potential to complete the college programme already begun. There was no evidence of psychosis. Although projective personality test data identified problems of anxiety management, identity, and sexuality, the patient did not manifest symptoms. Clinical observations and test results reflected a neurotic individual.

After rehabilitation, the patient was discharged to an independent living centre. Three months later, he had a major motor seizure during a glucose tolerance test. Phenytoin was initiated. Seven months later, the finger stumps had healed. After 4 more months, he was readmitted with pressure sores and open ulcers on the stumps. Serum phenytoin concentration was negligible, suggesting noncompliance. Therapy was reestablished and phenytoin levels were therapeutic. There were no signs of self-biting for the next 2 years, after which it recurred intermittently. 
Case 2

While on combat duty in Viet Nam, a 24-year-old man sustained a $\mathrm{C}_{4}$ complete $\mathrm{SCI}$ with transitional levels at $\mathrm{C}_{5-6}$ from bullet fire. Following this, he separated from his wife and son. He was hospitalised several times over the next few years for bilateral hamstring tenotomies, lumbar sympathectomy, management of multiple pressure sores, and circumcision and implantation of penile prostheses for a condom catheter. Medication included diazepam and propantheline bromide. Six years post-SCI, when admitted with ischial osteomyelitis, the patient chewed his nails and fingers leading to bleeding and displayed increasing frustration. He requested that his fingers be covered with tape, to thwart the biting. When discharged, the fingers were healed. When seen as an outpatient afterwards, he had eaten away flesh from 2 fingers, exposing bone. One distal phalanx had broken off. Another was completely denuded. Five years later, he was admitted with multiple infected, necrotic, communicating Grade IV (Enis, 1973; Shea, 1975) pressure sores and osteomyelitis of the hip. He reported that the sores had been present since his last hospitalisation but that his dislike for hospitals had kept him home. On physical examination, the two distal phalanges of the right middle, ring, and small fingers had been amputated. The right index finger had been amputated to the middle of the proximal phalanx. Significant scarring and clubbing were present. On the left, the index, ring, and small fingers had been amputated just distal to the metacarpal-phalangeal joints and bleeding ulcerations were present on the stumps. The patient explained that this was all due to persistent finger-nibbling. One penile implant was gone and the other was eroding though the penile skin. Laboratory values were within normal limits except for hypochromic, microcytic anemia and hypoalbuminemia $(2.8 \mathrm{~g} / \mathrm{dL})$ which required correction. Psychological: Past history was negative for emotional difficulty. Upon graduating from high school, the patient had been employed as a telephone company lineman. He attended college for a short time on a football scholarship but did poorly due to socialising. He left college to be married and was later drafted into the Army. He reported pre-SCI fingernail biting. He displayed severe self neglect. He was found to have bright normal intelligence and to be immature. He had been an underachiever and tended to exaggerate past deeds and accomplishments. He was overly self-confident regarding his abilities and future plans. Resumption of self-biting while hospitalised was related to his anxiety response to hospitals. He spoke freely of his self-mutilation but denied it was a problem. He tended to act out anger and depression. He was demanding and self-centered. The psychiatric diagnosis was of depressive neurosis.

During later hospitalisations, the patient stopped self-biting when staff focussed attention to it but when visited at home, he was found repeating the behaviour on several occasions.

\section{Discussion}

The term self-injurious behaviour (SIB) describes various repetitious acts directed by individuals toward themselves which impart physical harm or tissue damage (Dorsey, 1980; Schroeder, 1978; Tate, 1966); this includes self-biting. 

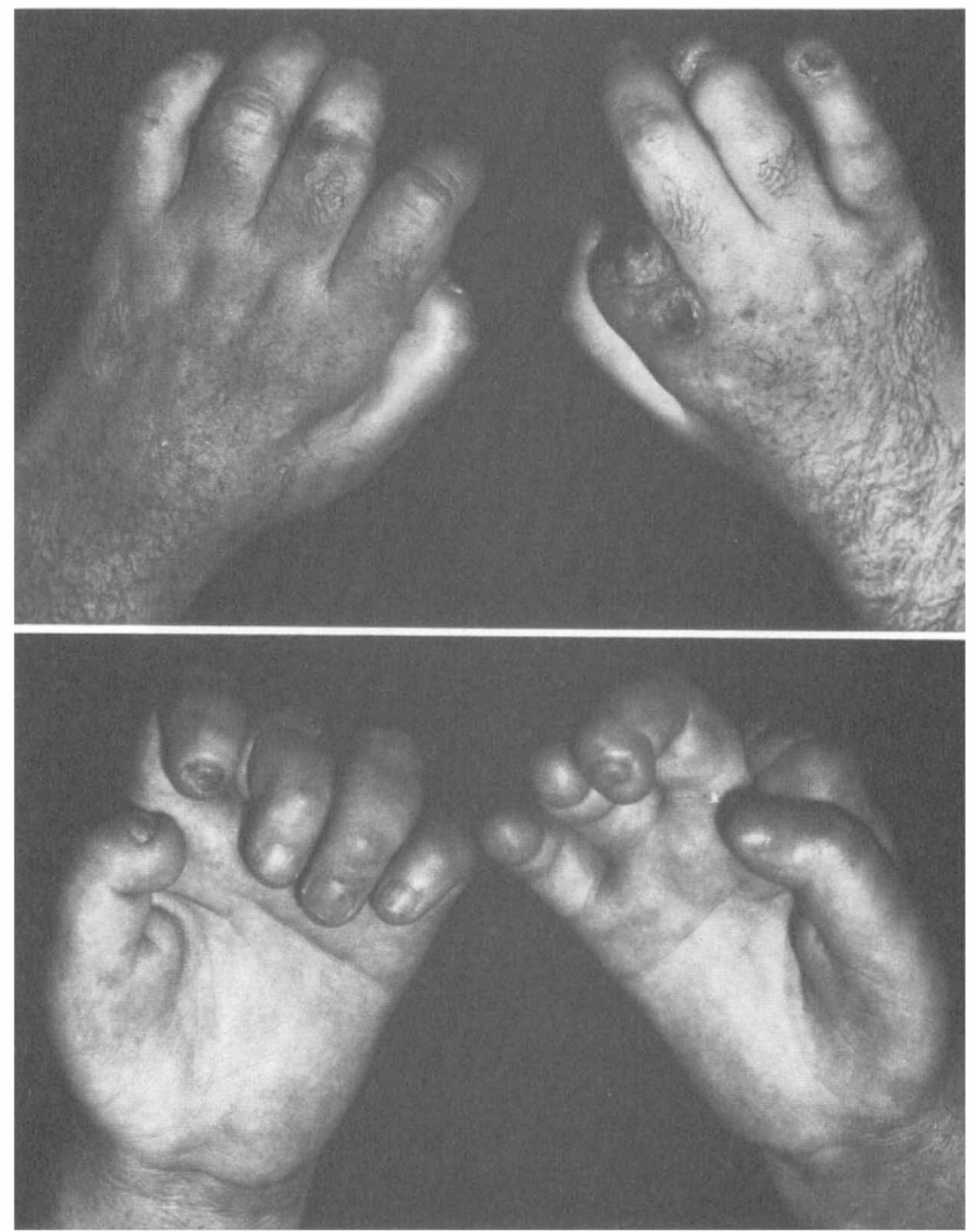

Figure 1. Photographs of hands (Case 1), demonstrating mutilation by self-biting. (A) (Dorsal View) Note amputations of right index finger and tip of right ring finger, trauma over knuckles, and damaged nail. (B) (Palmar View) Note damaged nails.

Self-biting of the upper extremities has been associated with a number of diagnoses but SCI has never been implicated prior to this report, as far as we can ascertain. SCI shares certain characteristics with some, but not all, of the conditions previously associated with this form of SIB.

Ballinger observed that 14 of 93 hospitalised persons with below normal intelligence quotients who engaged in SIB did so by biting, which was usually confined to the upper extremities (Ballinger, 1971). Self-biting has been noted in cases of microcephaly (Singh, 1980), following neonatal brain damage (Gross, 1980), and in mental retardation (Dorsey, 1982; Gaylord-Ross, 1980; Lockwood, 1982). Lesch-Nyhan Syndrome (LNS), an X-linked inborn error of metabolism, is characterised by mental retardation, spastic cerebral palsy, choreoathetosis, 

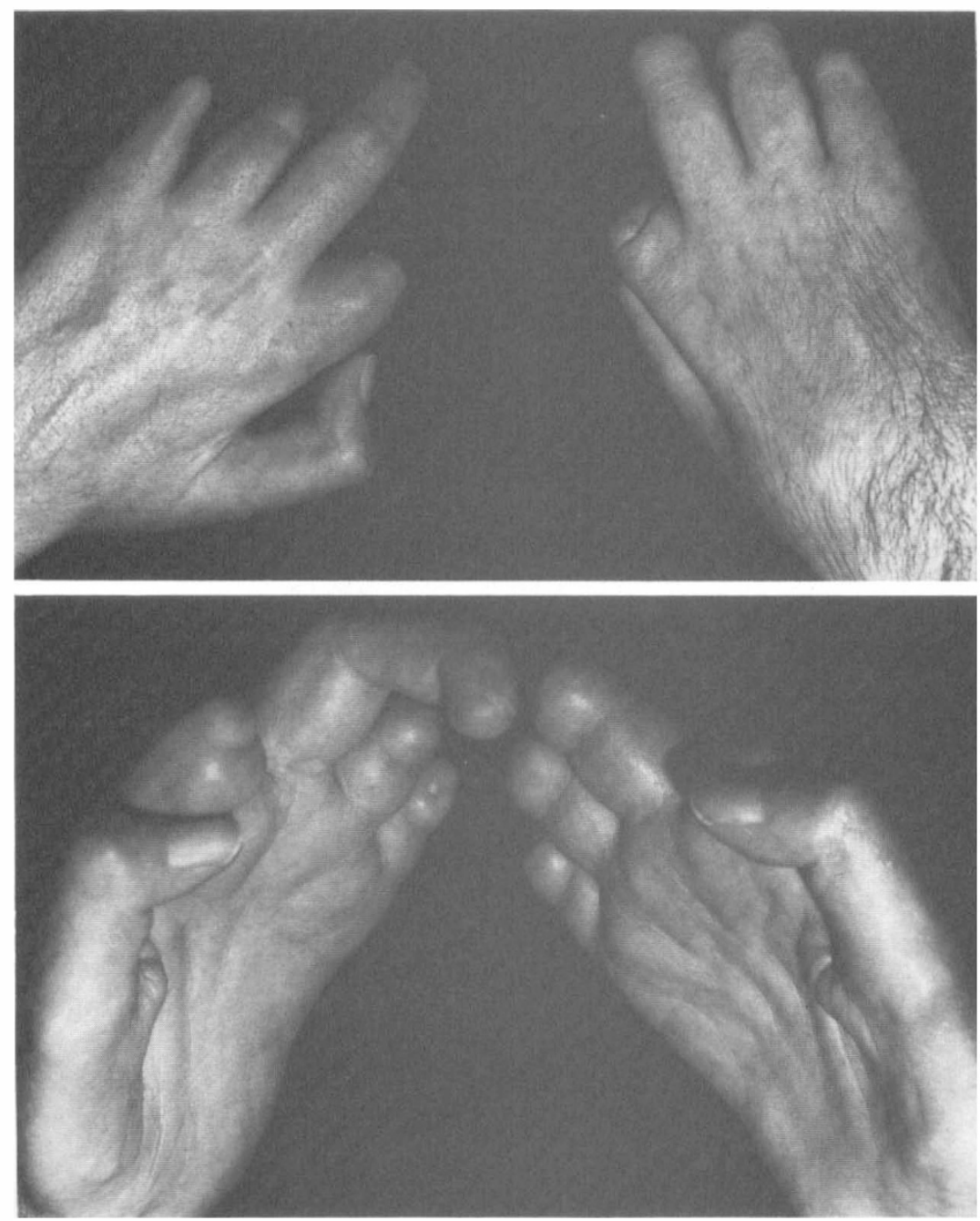

Figure 2. Photographs of hands (Case 2), demonstrating mutilation by self-biting. (A) (Dorsal View) Note bilateral multiple finger amputations. (B) (Palmar View) Note absence of trauma to thumbs bilaterally.

and compulsive self-biting of the lips, fingers, and hands (Anderson, 1978; Christie, 1982; Cudzinowski, 1979; Duker, 1975; Lesch, 1964; Nyhan, 1972; Nyhan, 1980). In one series, 3 of 15 hand/finger biters with LNS self-amputated portions of digits (Christie, 1982). Unlike these patient groups, our SCI patients had normal intellectual function. Unlike LNS patients, in whom sensory pathways are intact (Anderson, 1978; Cudzinowski, 1979; Seegmiller, 1980), our patients did have sensory deficits.

The most effective deterrent against the chewing away of viable tissue is probably pain sensation. Social mores also serve to dissuade self-biting. Persons with congenital abnormalities of pain perception have inflicted extreme selfmutilation upon themselves by biting, as in reversible somatotropin deficiency, which may be associated with pain agnosia (Money, 1972). Patients with 

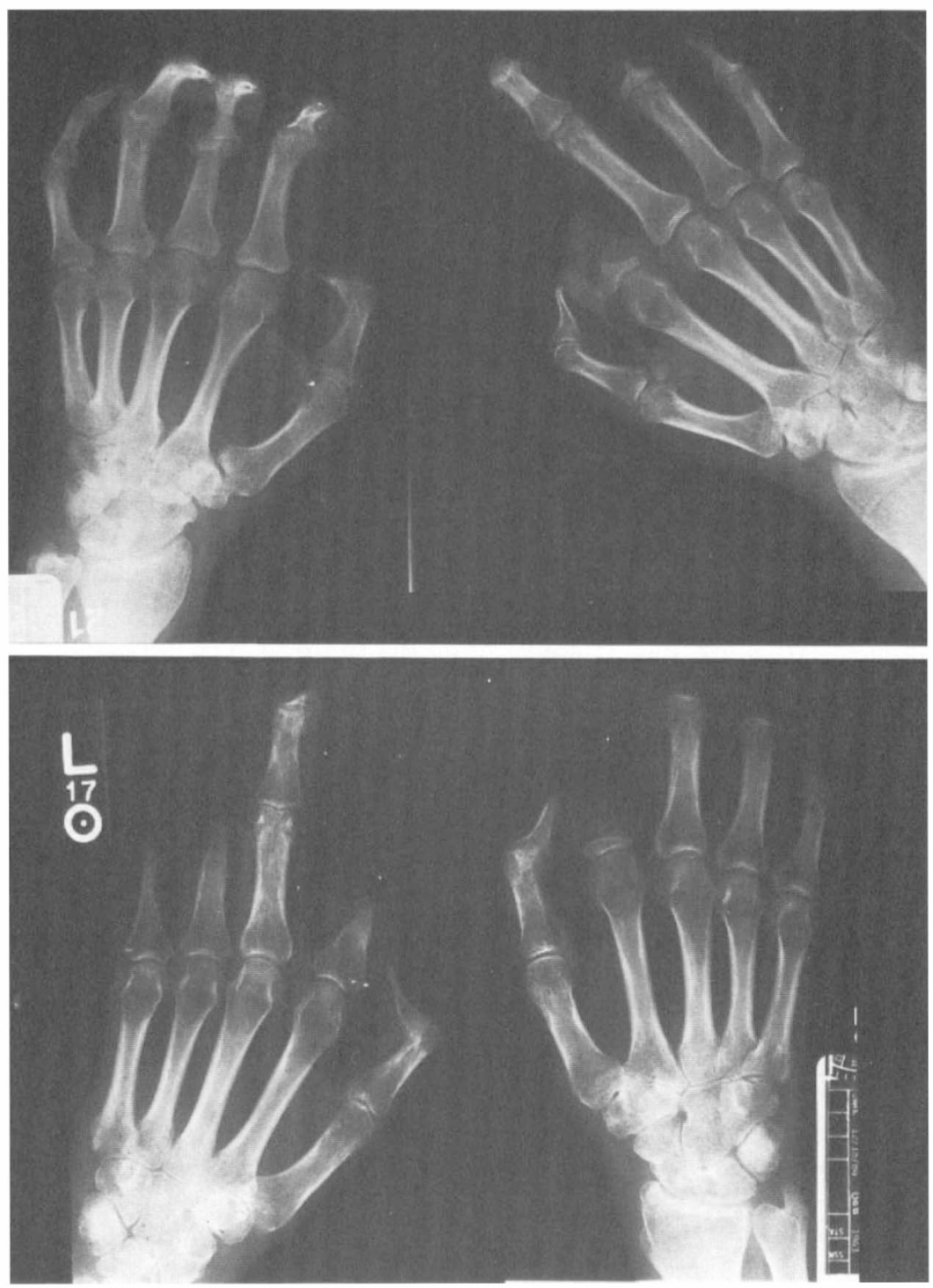

Figure 3. Roentgenograms of hands of Case 1 (3A) and Case 2 (3B), showing phalangeal loss and destruction due to self-biting.

congenital sensory neuropathy with anhidrosis begin self-chewing with the eruption of primary incisors (Lee, 1976; Mazar, 1976; Thompson, 1980). They are generally of low intelligence, with emotional disorders including autistic behaviour. They may present with numerous scars, calluses, abrasions, and nail deformity or loss (Pinsky, 1966; Thompson, 1980). Familial dysautonomia (Riley, 1957) has also been associated with SIB (Thompson, 1980).

Congenital sensory neuropathy without severe mental retardation leading to compulsive self-biting has been described (Haddow, 1970). Self-biting has been observed with a range of intellectual function, from borderline to 
superior, in cases of congenital indifference-to-pain (Appenzeller, 1972; Gwinn, 1966; Ingwersen, 1967; Jewesbury, 1951; MacEwen, 1970; McMurray, 1950; Saldanha, 1964; Thrush, 1973). One would expect that an individual with impaired sensory function, but normal comprehensive ability, would curtail self-biting upon visual recognition of bleeding, as described by Appenzeller (Appenzeller, 1972). Recognition of trauma, bone denudation, and amputations did not effectively attenuate self-biting in our SCI patients.

Boredom-induced self-biting has been described in the absence of sensory deficit (Fahmy, 1981). Certainly, boredom may have contributed to the behaviour of our patients, who spent much of their day bedridden and alone. Parenthetically, we have observed self-biting of the digital pulp in a third $\mathrm{C}_{4}$ complete SCI patient with normal intelligence who states that he bites his fingers out of boredom. Covert maternal deprivation has resulted in mutilative self-biting (Slaughter, 1977). Similarly, peer-infant separation syndrome has included handchewing in Macaque infants (Maxim, 1980). Both of our patients experienced relative social isolation following SCI. Carroll et al. state that non-suicidal self-mutilation is typically followed by a sense of calm, relief, and decreased tension. They related self-inflicted injury in adults to excessive violence in the home during childhood and to physical abuse by parents (Carroll, 1980). We are unaware of such childhood experiences in our patients.

Wart-like hyperkeratotic lesions due to gnawing of the dorsal aspects of the hands has occurred in response to stress (MacWilliams, 1974). Spontaneous self-aggression including extensive biting of the upper limbs has also developed in housed Macaques experiencing stress (Pond, 1983). Both of our patients related fingernail biting, which progressed to severe mutilation, to anxiety and depression. It has been found that disfigurement, embarrassment, and comments from peers do not necessarily diminish self-mutilative behaviours (Azrin, 1982). Our patients were both very self-conscious of the appearance of their hands after the finger amputations and yet both were observed repeating the self-biting behaviour.

Two cases from the literature resemble ours in terms of central nervous system involvement. Altman et al. described SIB in a one-year-old child with spina bifida and normal intellectual function. Pin-prick and temperature sensitivities were normal on the right upper extremity but not on the left. Normal withdrawal response was elicited by testing all areas except the left forearm and hand. Frequent episodes of finger-biting led to severe trauma of the left index finger (Altman, 1983). Arons et al. recently reported self-mutilation of the hands by chewing in a female born with a large cervical meningomyelocele, which was surgically repaired after birth. She began chewing her hands at age 3 months and was able to describe pain and itching of the fingers at age 2 years. By age 6 , tissue destruction and osteomyelitis had resulted. The thumbs were eaten away. She had normal mentation. Iron deficiency anemia was felt to be the result of a prolonged daily loss of blood due to biting (Arons, 1984). Anemia and hypoalbuminemia in our second patient were believed to be due to poor nutritional intake and extensive pressure sores, to which bleeding finger ulcerations probably contributed.

Self-biting behaviours associated with neurologic deficits resemble the phenomenon of post-neurosurgical mutilative self-chewing in animals. Multiple 
dorsal rhizotomy or spinal cord trauma induce predictable self-chewing with amputations (Basbaum, 1974; Lombard, 1979; Sweet, 1981; Wiesenfeld, 1980). Increased pain-related activity accelerates this type of biting (Dennis, 1979). In a unique study, Berman and Rodin investigated the combined effects of $T_{13}-L_{6}$ unilateral dorsal rhizotomy and isolation. Rats chewed the ipsilateral hindlimb and contiguous area when isolated pre- and postoperatively. Rats isolated preoperatively but paired postoperatively displayed no chewing (Berman, 1982), implicating isolation as a factor in self-biting.

In the unilaterally deafferented cat, spontaneously hyperactive neurons have been found in the dorsal horns bilaterally, from one cord segment below to two segments above the rhizotomised region. Lumbar cord hemisection is followed by spontaneous hyperactivity on the side of the lesion (Loeser, 1967). These findings support a quasi-epileptic focal etiology of self-biting in animals, in which contralateral inhibitory pathways may play a suppressant role (Duckrow 1977). High frequency and burst firing patterns from $T_{10}$ to $L_{1}$ have also been seen in human $\mathrm{L}_{1}$ complete SCI (Loeser, 1968).

Management of self-biting involves behaviour modification, which has often proven ineffective. Restraints have produced bone demineralisation, tendon shortening, and reduced motor function (Dorsey, 1982; Lovaas, 1969) and could lead to pressure sores. While the efficacy of drugs in reducing SIB has produced varying results (Ballinger, 1971; Schroeder, 1978), selective pharmacologic manipulation has provided clues to understanding the behaviour.

Neuroleptics, such as droperidol (Burns, 1980) and chlorpromazine (McKinney, 1973) have attenuated self-mutilation in humans and Macaques. Their antiserotonergic action suggests self-biting is mediated by serotonin (SER) but the effectiveness of lithium therapy (Cooper, 1972; Sovner, 1981) suggests that the behaviour is initiated by relative SER depletion. Animal studies have supported the theory that self-biting in LNS is due to central dopaminergic dysfunction (Mueller, 1982; Mueller, 1982; Mueller, 1983). Decreased striatal dopamine (DA) neuron terminal function in LNS (Lloyd, 1981) implicates DA receptor supersensitivity (Mueller, 1982). Clinically, striking reduction in selfbiting in LNS using a SER precursor gives credence to the hypothesis that the behaviour in LNS is due to subnormal central SER levels (Muzino, 1974; Nyhan, 1980), although some researchers disagree (Anderson, 1976; Buzas, 1981; Frith, 1976).

The narcotic antagonist naloxone attenuates or eliminates self-abusive episodes in mentally retarded patients with extensive history of SIB, possibly due to pain threshold lowering. SIB may be related to blunted nociception maintained by endogenous beta endorphins (Sandman, 1983). SIB could be a type of reinforced addictive response to the release of endorphins by pain-inducing behaviour (Richardson, 1983).

In rats, after unilateral $\mathrm{C}_{5}-\mathrm{T}_{1}$ dorsal rhizotomy, self-chewing progressing to amputations, often to the elbow, occurred in 89 per cent without treatment and in 45 per cent with phenytoin treatment (Duckrow, 1977). While this supports the quasi-epileptic focus theory of self-biting, phenytoin also accelerates SER synthesis in the brain (Green, 1978), again implicating SER depletion. Arons' meningomyelocele patient responded to phenytoin when the antiepileptic diminished her dysesthesias (Arons, 1984). It is interesting that our first patient 
nibbled his fingers extensively during a phenytoin-free period, although these are unscientific observations made retrospectively.

As discussed, SIB has been linked to central neurochemical alterations. Since stress and SCI have also been associated with such imbalances, they may contribute to SIB through that mechanism. SER activity increases (Culman, 1984; Driscoll, 1983; Richardson, 1984; Yehuda, 1984) or decreases (Driscoll, 1983; Smythe, 1983) in areas of the brain after stress. In humans, central SER stores are depleted (Hoes, 1982).

Elevation of central DA activity follows stress (Herman, 1982; Jensen, 1982; Miller, 1984; Reinhard, 1982; Richardson, 1984; Saavedra, 1981). Sterotypic behaviour in stressed pigeons is reduced by the neuroleptic haloperidol, apparently via DA antagonism (Goodman, 1983). In rats, stress-induced acceleration of DA metabolism in the medial frontal cortex can be reversed by naloxone, implying endogenous opioid facilitation of the DA stress response (Miller, 1984). DA antagonism could have been responsible for the reduction by naloxone of self-abusive behaviour reported by Sandman et al. (Sandman, 1983).

SCI is followed by long periods of adjustment, often extending to years and often accompanied by emotional stress. Central neurochemical imbalances might occur, as a result. Research has defined catecholamine fluctuations around the site of experimental SCI (Alderman, 1980; Bingham, 1975; Brodner, 1977; Brodner, 1980; Hinwood, 1980; Naftchi, 1981; Nemecek, 1977; Rodriguez, 1977; Shigetomi, 1980; Zivin, 1976) but the focus has been on acute cord response to trauma, rather than chronic abnormalities. Questions remain concerning SER and DA changes which may accompany the chronic SCI state, which might be compounded by stress, and which could contribute to self-biting.

\section{Conclusion}

Self-biting of the upper extremities has generally been associated with specific pathology or physiologic abnormality or with mental retardation but the actual underlying cause continues to elude researchers. Certain factors may predispose an individual to self-biting. We believe that the fingernail biting habits and neurotic personalities of our two patients provided a foundation for this behaviour. After they sustained $\mathrm{C}_{4}$ complete $\mathrm{SCI}$, the contributory effects of stress, isolation, and most importantly loss of sensation resulted in the development of self-biting and led to multiple finger amputations. Alterations in central neurotransmitters and neuronal hyperactivity may have also been factors.

\section{Acknowledgement}

The authors wish to thank Charles Garrett, M.A., Library Technician, for his invaluable contributions toward the completion of this paper.

\section{Résumé}

Nous avons observé deux patients traumatisés médullaires $\mathrm{C}_{4}$ complets qui ont rongé leurs doigts de façon très mutilante. Les deux patients étaient de sexe masculin, d'intelligence normale, ne 
présentant aucun signe de psychose. Les deux ont une personnalité neurontique et des antécédents d'avoir été des 'rongeurs d'ongle.' D'après eux, l'anxiété et la dépression en sont responsables. Nous pensons que ces deux cas sont les premiers à être presentés dans la presse medicale en langue anglaise.

\section{Zusammenfassung}

Wir berichten über 2 Fälle von Selbstverstümmelung, wobei die Patienten irhen eigenen Finger abgenagt haben. Beide Patienten waren $\mathrm{C}_{4}$ Rückenmarkverletze mit normaler Intelligenz und neurotischer Persönlichkeit. Psychose war nicht diagnostiziert. Sie haben eine Vorgeschichte von Nagel beissen. Sie klagten, dass Angst und Niedergeschlagenheit dafür verantwortlich waren. Es ist uns nicht gelungen anderen Fälle von Rückenmarkverletzung mit Selbstverstümmelung der Finger und Händen in der englischen Litteratur zurückzufinden.

\section{References}

Alderman JL, Osterholm JL, D'Amore BR, Williams HD 1980 Catecholamine alterations attending spinal cord injury: a reanalysis. Neurosurgery 6: 412-417.

Altman K, HaAvik S, Higgins ST 1983 Modifying the self-injurious behavior of an infant with spina bifida and diminished pain sensitivity. Journal of Behavior Therapy \& Experimental Psychiatry 14:165-168.

ANDERSON L, DANCIS J, ALPERT M 1978 Behavior contingencies and self-mutilation in LeschNyhan Disease. Journal of Consulting and Clinical Psychology, 46:529-536.

ANDERSON LT, HERMANN L, DANCIS J 1976 The effect of 1-5-hydroxytryptophan on selfmutilation in Lesch-Nyhan disease: a negative report. Neuropaediatrie, 7:439-442.

APPENZELLER O, KORNFELD M 1972 Indifference to pain: a chronic peripheral neuropathy with mosaic Schwann cells. Archives of Neurology, 27:322-339.

ARons MS, LATtanzi WE, Levy LL, RIFkIN B 1984 Severe self-mutilation of hands in a nonpsychotic, nonretarded patient. Plastic and Reconstructive Surgery, 74:282-286.

AZRIN NH, NUNN RG, FRANTZ SE 1980 Habit-reversal vs. negative practice treatment of nailbiting. Behavior Research and Therapy, 18:281-285.

AZRIN NH, NuNN RG, FRANTZ-RENSHAw SE 1982 Habit-reversal vs. negative practice treatment of self-destructive oral habits (biting, chewing or licking of the lips, cheeks, tongue or palate). Journal of Behavior Therapy \& Experimental Psychiatry, 13:49-54.

BALLINGER BR 1970 The prevalence of nail-biting in normal and abnormal populations. British Journal of Psychiatry, 117:445-446.

BALLINGER BR 1971 Minor self-injury. British Journal of Psychiatry, 118:535-538.

BASBAUM AI 1974 Effects of central lesions on disorders produced by multiple dorsal rhizotomy in rats. Experimental Neurology, 42:490-501.

BARMANN BC 1979 The use of overcorrection with artificial nails in the treatment of chronic fingernail biting. Mental Retardation, 17:309-311.

BERMAN D, RODIN BE 1982 The influence of housing condition on autonomy following dorsal rhizotomy in rats. Pain, 13:307-311.

Bingham WG, Ruffolo R, Friedman SJ 1975 Catecholamine levels in the injured spinal cord of monkeys. Journal of Neurosurgery, 42:174-178.

BIRCH LB 1955 The incidence of nail-biting among school-children. British Journal of Educational Psychology, 25:123-128.

Bornstein PH, RychtaRik RG, MCFall ME, Winegardner J, Winnett RL, Paris DA 1980 Hypnobehavioral treatment of chronic nailbiting: a multiple baseline analysis. International Journal of Clinical and Experimental Hypnosis, 28:208-217.

BRODNER RH, DOHRMANN GJ 1977 Norepinephrine, dopamine and serotonin in experimental spinal cord trauma: current status. Paraplegia, 15:166-171.

Brodner RH, Dohrmann GJ, Roth RH, Rubin RH 1980 Correlation of cerebrospinal fluid serotonin and altered spinal cord blood flow in experimental trauma. Surgical Neurology, 13:337-343.

BUCHER BD 1968 A pocket-portable shock device with application to nailbiting. Behaviour Research and Therapy, 6:389-392.

BURNS ME 1980 Droperidol in the management of hyperactivity, self-mutilation and aggression in mentally handicapped patients. Journal of International Medical Research, 8:31-33.

Buzas HP, Ayllon T, Collins R 1981 A behavioral approach to eliminate self-mutilative behavior in a Lesch-Nyhan patient. Journal of Mind and Behavior, 2:47-56.

Carroll J, Schaffer C, SPensley J, Abromowitz SI 1980 Family experiences of self-mutilating patients. American Journal of Psychiatry, 137:852-853.

Christie R, Bay C, Kaufman IA, Bakay B, Borden M, Nyhan WL 1982 Lesch-Nyhan disease: clinical experience with nineteen patients. Developmental Medicine and Child 
Neurology, 24:293-306.

ClARK DF 1970 Nail-biting in subnormals. British Journal of Medical Psychology, 43:69-81.

COOPER AF, Fowlie HC 1972 Control of gross self-mutilation with lithium carbonate. British Journal of Psychiatry, 122:370-371.

Cudzinowski L, Perreault JG 1979 The Lesch-Nyhan syndrome: report of a case. ASDC Journal of Dentistry for Children, 46:143-144.

Culman J, Kiss A, KvetNANSKy R 1984 Serotonin and tryptophan hydroxylase in isolated hypothalamic and brain stem nuclei of rats exposed to acute and repeated immobilization stress. Experimental and Clinical Endocrinology, 83:28-36.

DAvidson AM, DenNey DR, ElliotT CH 1980 Suppression and substitution in the treatment of nailbiting. Behaviour Research and Therapy, 18:1-9.

DEARDORFF PA, FINCH AJ, ROYALl LR 1974 Manifest anxiety and nail-biting. Journal of Clinical Psychology, 30:378.

DENNIS SG, MELZACK R 1979 Self-mutilation after dorsal rhizotomy in rats: effects of prior pain and pattern of root lesions. Experimental Neurology, 65:412-421.

DORSEY MF, IwATA BA, ONG P, MCSWEEN TE 1980 Treatment of self-injurious behavior using a water-mist: initial response suppression and generalization. Journal of Applied Behavior Analysis, 13:343-353.

DoRSEy MF, IwATA BA, Reid DH, DAvis PA 1982 Protective equipment: continuous and contingent application in the treatment of self-injurious behavior. Journal of Applied Behavior Analysis, 15:217-230.

Driscoll P, Dedek J, Martin JR, Zivrovic B 1983 Two-way avoidance and acute shock stress induced alterations of regional noradrenergic, dopaminergic and serotonergic activity in Roman high- and low-avoidance rats. Life Sciences, 33:1719-1725.

DUCKROW RB, TAUB A 1977 The effect of diphenylhydantoin on self-mutilation in rats produced by unilateral multiple dorsal rhizotomy. Experimental Neurology, 54:33-41.

DUKER P 1975 Behavior control of self-biting in a Lesch-Nyhan patient. Journal of Mental Deficiency Research, 19:11-19.

ELLERBROEK WC 1978 Personal disarmament: nail-biting as a behavior. Journal of the American Society of Psychosomatic Dentistry and Medicine, 25:7-11.

ENIS JE, SARMIENTo A 1973 The pathophysiology and management of pressure sores. Orthopedic Review, 2:25-34.

FaHMY NRM, Noble J 1981 Digital osteomyelitis due to boredom. The Hand, 13:285-286.

Frith CD, Johnston EC, Joseph MH, Powell RJ, Watts RW 1976 Double-blind clinical trial of 5-hydroxytryptophan in a case of Lesch-Nyhan syndrome. Journal of Neurology, Neurosurgery, and Psychiatry, 39:656-662.

GAYLORD-ROSS RJ, WEEKS M, LIPNER C 1980 An analysis of antecedent, response, and consequence events in the treatment of self-injurious behavior. Education and Training of the Mentally Retarded, 15:35-42.

Goodman I, Zacny J, Osman A, Azzaro A, Donovan C 1983 Dopaminergic nature of feeding-induced behavioral stereotypies in stressed pigeons. Pharmacology, Biochemistry \& Behavior, 18:153-158.

Green AR, Grahame-SMITH DG 1978 Processes regulating the functional activity of brain 5hydroxytryptamine: results of animal experimentation and their relevance to the understanding and treatment of depression. Pharmakopsychiatria, 11:3-16.

Gross AM, WRIGHT B, DRABMAN RS 1980 The empirical selection of a punisher for a retarded child's self-injurious behavior: a case study. Child Behavior Therapy, 2:59-65.

GRUENEWALD D 1965 Hypnotherapy in a case of adult nailbiting. International Journal of Clinical and Experimental Hypnosis, 13:209-219.

Gwinn JL, BARNes GR, TUCKeR AS, Johnson C 1966 Radiological case of the month. American Journal of Diseases of Children, 112:583-584.

HADDOW JE, SHAPIRO SR, GALL DG 1970 Congenital sensory neuropathy in siblings. Pediatrics, 45:651-655.

Herman JP, Guillonneau D, Danzter R, Scatton B, Semerdjian-Rouquier L, Le Moal M 1982 Differential effects of inescapable footshocks on dopamine turnover in cortical and limbic areas of the rat. Life Sciences, 30:2207-2214.

HILL JM 1946 Nail-biting, incidence, allied personality traits and military significance. American Journal of Psychiatry, 103:185-187.

Hinwood BG, YEO JD, KIDMAN AD 1980 Monoamine and tissue fluid levels in contused spinal cord of sheep. Journal of Neurochemistry, 35:786-791.

HoEs MJ 1982 Monoamines in psychiatry: the role of serotonin in depression, anxiety and stress. Acta Psychiatrica Belgica, 82:287-309.

HoRNE DJ, WILKINSON J 1980 Habit reversal treatment for fingernail biting. Behaviour Research and Therapy, 18:287-291.

INGWERSEN OS 1967 Congenital indifference to pain: report of a case. Journal of Bone and 
Joint Surgery, 49B, 704-709.

JENSEN TS, SMITH DF 1982 Monoaminergic mechanisms in stress-induced analgesia. Journal of Neural Transmission, 53:247-255.

JEWESBURY ECO 1951 Insensitivity to pain. Brain, 74, 336-353.

Klatte KM, DeardorfF PA 1981 Nail-biting and manifest anxiety of adults. Psychological Reports, 48:82.

KOUPERNIK C 1964 L'onychophagie. Concours Medical, 86:711-713.

Lee EL, Oh GC, Lam KL, Parameswaran N 1976 Congenital sensory neuropathy with anhidrosis: a case report. Pediatrics, 57:259-262.

LESCH M, NYHAN WL 1964 A familial disorder of uric acid metabolism and central nervous system function. American Journal of Medicine, 36:561-570.

Lloyd KG, Hornykiewicz O, Davidson L, Shannak K, Farley I, Goldstein M, Shibuya M, KELLEY WN, Fox IH 1981 Biochemical evidence of dysfunction of brain neurotransmitters in the Lesch-Nyhan syndrome. New England Journal of Medicine, 305:1106-1111.

Lockwood K, Bourland G 1982 Reduction of self-injurious behaviors by reinforcement and toy use. Mental Retardation, 20:169-173.

LOESER JD, WARD AA 1967 Some effects of deafferentation on neurons of the cat spinal cord. Archives of Neurology, 17:629-636.

LOESER JD, WARD AA, WhITE LE 1968 Chronic deafferentation of human spinal cord neurons. Journal of Neurosurgery, 29:48-50.

Lombard MC, Nashold BS, Albe-Fessard D, Salman N, Sakr C 1979 Deafferentation hypersensitivity in the rat after dorsal rhizotomy: a possible animal model for chronic pain. Pain, 6:163-174.

Lombard MC, Nashold BS, Pelissier T 1979 Thalamic recordings in rats with hyperalgesia. Advances in Pain Research and Therapy, 3:767-772.

LovaAs OI, Simmons JQ 1969 Manipulation of self-destruction in three retarded children. Journal of Applied Behavior Analysis, 2:143-157.

LOWRY TP 1965 Bedwetting and nailbiting in military recruits. Military Medicine, 130:47-54.

MACEWEN GD, FLOYD GC 1970 Congenital insensitivity to pain and its orthopedic implications. Clinical Orthopaedics and Related Research, 68:100-107.

MacWilliams P, Lee JM, Noojin RO 1974 Gnaw Warts. Southern Medical Journal, 67:643-644.

MALONE AJ, MASSLER M 1952 Index of nail-biting in children. Journal of Abnormal Social Psychology, 47:193-202.

Massler M, Malone AJ 1950 Nail-biting, a review. Journal of Paediatrics, 36:523-531.

MAXIM PE 1980 Rewarding brain stimulation and the peer-infant separation syndrome. Physiology \& Behavior, 25:53-61.

MAZAR A, HeRold HZ, VARDY PA 1976 Congenital sensory neuropathy with anhidrosis: orthopedic complications and management. Clinical Orthopaedics and Related Research, 118:184-187.

MCKERRACHER DW, WATSON RA 1967 Nail biting in subnormal psychopaths. Journal of Mental Subnormality, 13:24-31.

MCKInNey WT, Young LD, Suomi SJ, Davis JM 1973 Chlorpromazine treatment of disturbed monkeys. Archives of General Psychiatry, 29:490-494.

MCMURRAY GA 1950 Experimental study of a case of insensitivity to pain. Archives of Neurology and Psychiatry, 64:650-667.

MCNAMARA JR 1972 The use of self-monitoring techniques to treat nailbiting. Behaviour Research and Therapy, 10:193-194.

Miller JD, Speciale SG, McMillen BA, German DC 1984 Naloxone antagonism of stressinduced augmentation of frontal cortex dopamine metabolism. European Journal of Pharmacology, 98:437-439.

Mizuno T, YUgari Y 1974 Self-mutilation in Lesch-Nyhan syndrome. Lancet, 1:761

Money J, WolfF G, ANNEcillo C 1972 Pain agnosia and self-injury in the syndrome of reversible somatotropin deficiency (psychosocial dwarfism). Journal of Autism and Childhood Schizophrenia, 2:127-139.

Mueller K, NyHAN WL 1982 Pharmacologic control of pemoline induced self-injurious behavior in rats. Pharmacology, Biochemistry \& Behavior, 16:957-963.

Mueller K, Saboda S, Palmour R, Nyhan WL 1982 Self-injurious behavior produced in rats by daily caffeine and continuous amphetamine. Pharmacology, Biochemistry \& Behavior, 17:613-617.

MUeller K, NyHaN WL 1983 Clonidine potentiates drug induced self-injurious behavior in rats. Pharmacology, Biochemistry \& Behavior, 18:891-894.

NAFTCHi NE, KIRSCHNER AK, DEMENY M, ViaU AT 1981 Alterations in norepinephrine, serotonin, c-AMP, and transsynaptic induction of tyrosine hydroxylase after spinal cord transection in the rat. Neurochemical Research, 6:1205-1216. 
Nemecex S, Suba P, Cerman J 1977 Serotonin in contused spinal cord. Acta Neurochirurgica, 39:53-58.

NyHaN WL 1972 Clinical features of the Lesch-Nyhan syndrome. Archives of Internal Medicine, 130:186-192.

NyHaN WL, Johnson HG, KaUfman IA, Jones KL 1980 Serotonergic approaches to the modification of behavior in the Lesch-Nyhan syndrome. Applied Research in Mental Retardation, 1:25-40.

Pennington LA 1945 The incidence of nailbiting among adults. American Journal of Psychiatry, 102:241-244.

Pinsky L, Digeorge AM 1966 Congenital familial sensory neuropathy with anhidrosis. Journal of Pediatrics, 68:1-13.

PoND CL, RUSH HG 1983 Self-aggression in macaques: five case studies. Primates, 24:127-134.

REINHARD JF, BANNON MJ, Roth RH 1982 Acceleration by stress of dopamine synthesis and metabolism in prefrontal cortex: antagonism by diazepam. Naunyn Schmiedeberg's Archives of Pharmacology, 318:374-377.

RichARDSON JS, ZALESKI WA 1983 Naloxone and self-mutilation. Biological Psychiatry, 18:99-101.

RICHARDSON JS 1984 Brain part monoamines in the neuroendocrine mechanisms activated by immobolization stress in the rat. International Journal of Neuroscience, 23:57-67.

RILEY CM 1957 Familial dysautonomia. Advances in Pediatrics, 9:157-190.

RodRigues M, SAHgal V, Subramani V 1977 Neurotransmitters in spinal cord injury. Archives of Physical Medicine and Rehabilitation, 58:547-554.

SAAVEDRA JM 1982 Changes in dopamine, noradrenaline and adrenalin in specific septal and preoptic nuclei after acute immobilization stress. Neuroendocrinology, 35:396-401.

Saldanha PH, Schmidt BJ, Nelson L 1964 A genetical investigation of congenital analgesia.

II. Clinico-genetical studies. Acta Genetica et Statistica Medica, 14:143-158.

Sandman CA, Datta PC, Barron J, Hoehler FK, Williams C, Swanson JM 1983 Naloxone attenuates self-abusive behavior in developmentally disabled clients. Applied Research in Mental Retardation, 4:5-11.

Schroeder SR, Schroeder CS, Smith B, Dalldorf J 1978 Prevalence of self-injurious behaviors in a large state facility for the retarded: a three-year follow-up study. Journal of Autism and Childhood Schizophrenia, 8:261-269.

SEEGMILLER JE 1980 Lesch-Nyhan disease and its variants. In: Bondy PK \& Rosenberg LE eds., Metabolic Control and Disease, 8th Ed., WB Saunders: Philadelphia, pp. 827-841.

SHEA JD 1975 Pressure sores: classification and management. Clinical Orthopaedics and Related Research, 112:89-100.

Shigetomi Y 1980 Biogenic amine study in the spinal cord of experimental cervical myelopathy. Nippon Seikeigeka Gakkai Zasshi, 54:371-380.

SINGH NN 1980 The effects of facial screening on infant self-injury. Journal of Behavior and Experimental Psychiatry, 11:131-134.

SLAUGHTER WG, CoRDES CK 1977 Covert maternal deprivation and pathological sucking behavior. American Journal of Psychiatry, 134:1152-1153.

SMYTHE GA, BRADSHAW JE, VINING RF (1983). Hypothalamic monoamine control of stressinduced adrenocorticotropin release in the rat. Endocrinology, 113:1062-1071.

SOVNER R, HURLEY A 1981 The management of chronic behaviour disorders in mentally retarded adults with lithium carbonate. The Journal of Nervous and Mental Disease, 169:191-195.

SWEET WH 1981 Animal models of chronic pain: their possible validation from human experience with posterior rhizotomy and congenital analgesia. Pain, 10:275-295.

TATE BG, BAROFF GS 1966 Aversive control of self-injurious behavior in a psychotic boy. Behaviour Research and Therapy, 4:281-287.

Thompson CC, PARK RI, Prescott GH 1980 Oral manifestations of the congenital insensitivityto-pain syndrome. Oral Surgery, Oral Medicine, Oral Pathology, 50:220-225.

THRUST DC 1973 Congenital insensitivity to pain: a clinical, genetic and neurophysiological study of four children from the same family. Brain, 96:369-386.

WECHSLER D 1931 The incidence and significance of finger-nail biting in children. Psychoanalytic Review, 18:201-209.

WiESENFELD Z, LINDBLOM U 1980 Behavioral and electrophysiological effects of various types of peripheral nerve lesions in the rat: a comparison of possible models for chronic pain. Pain, 8:285-298.

YEHUDA R, MEYER JS 1984 A role for serotonin in the hypothalamic-pituitary-adrenal response to insulin stress. Neuroendocrinology, 38:25-32.

Zivin JH, Doppman JL, Reid JL, Tappaz ML, SaAvedra JM, Kopin IJ, Jacobowitz DM 1976 Biochemical and histochemical studies of biogenic amines in spinal cord trauma. Neurology, 26:99-107. 